\section{Michael Brintnall to Move to NASPAA}

Michael Brintnall, who has been Director of Professional Affairs at APSA since 1990, has been named Executive Director of the National Association of Schools of Public Affairs and Administration (NASPAA). At APSA, Brintnall has provided staff support for APSA committees on professional ethics, research support, organized sections, and lesbians and gays in the profession, worked with APSA's Minority Identification Project, led in developing the Association's management information systems and Internet connections, and reported periodically in $P S$ on developments in the political science professoriate and job market.

NASPAA is a national association of 230 American universities and colleges offering degrees in public affairs and administration, located in Washington D.C. Brintnall's work there will keep him in regular contact with the political science and public administration community and the American Political Science Association.

\section{APSA Changes Dues Categories and Increases Some Dues}

The APSA Council modified dues categories at its April meeting, increasing dues for the first time since 1990 , restructuring some dues categories, and adding a new reduced dues option for unemployed political scientists. The Council also began a process of annual reviews of dues levels with the intent of making small periodic adjustments rather than delaying increases until larger jumps are necessary.

The dues restructuring is intended to make dues categories more fair and to reflect current salary levels better in addition to increasing dues revenue modestly. Added revenues would counter a decline since 1990 in the real share of total APSA revenues which comes from individual members. Anticipated revenue increases to

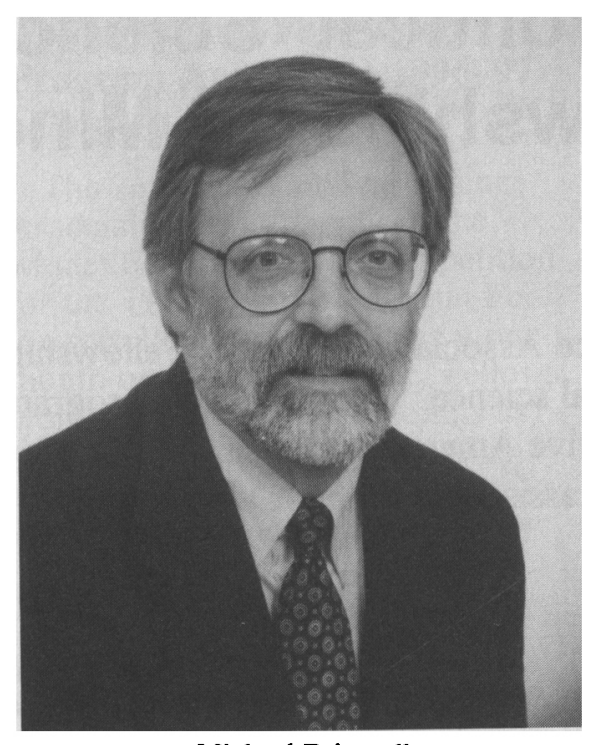

Michael Brintnall

the Association will be about 2 percent of APSA's budget.

Specific dues changes are as follows:

- allow unemployed political scientists to become APSA members at the student rate. (The five year limitation on use of this rate would also apply.) This affords a significant subsidy to political scientists in need.

- increase student rates from $\$ 25$ to $\$ 30$ per year.

- increase dues for the lowest professional category (called R1) from $\$ 55$ to $\$ 65$. The income limit would remain at under $\$ 30,000$. The median academic year salary for assistant professors is $\$ 36,000$.

- increase the dues for the R2 category- $\$ 30,000$ to $\$ 40,000$-from $\$ 75$ to $\$ 80$. This reduces the differential between R1 and R2 from $\$ 20$ to $\$ 15$, perhaps helping members more fairly judge in which category they fall.

- increase the R3 and R4 categories each by $\$ 10$ to $\$ 95$ and $\$ 105$ respectively, and increase the upper income range for $\mathrm{R} 4$ from $\$ 60,000$ to $\$ 70,000$.

- set the R5 salary cut-off at greater than $\$ 70,000$, and increase it to $\$ 125$.

- set increases in Associate member dues from $\$ 25$ to $\$ 35$ and in family member dues from $\$ 10$ to $\$ 15$ to help cover increased costs of processing such memberships.
- increase the life membership rate to $\$ 3000$ from $\$ 2000$.

APSA professional membership has grown steadily since the mid1980s. However, except for the effects of the last dues increase in 1990 , the total revenue from professional dues in constant dollars has not shown growth, and revenues since 1990 have begun to decline. Member dues are also a decreasing percentage of total APSA revenues. Total revenue has grown more from increases in other sources, such as publication sales and annual meeting exhibitors, than from dues.

The Association has also increased dues for domestic institutional memberships (primarily libraries) to $\$ 200$. This increase was necessary to match rapidly increasing costs of paper and postage.

\section{Association Awards 1996 Research Grants}

The APSA Research Support Committee recently made awards totalling $\$ 18,000$ to 12 scholars as part of the Association's Research Grant program. APSA Research Grants are funded directly by the Association to support research by independent scholars and faculty in colleges and universities that do not award a Ph.D. in political science. This year funded projects include studies of international adjudication, identity politics and two-level games, voting by mail, racial barriers, the etiology of individual intolerance, guidelines in family courts, the presidency and social issues, changes in Venezuelan democracy, nation building in Southern Africa, and the women's movement in El Salvador.

The Committee evaluated 54 proposals this year totalling $\$ 88,711$ in requested funds. Last year, 52 proposals were received totalling $\$ 71,000$. Total funds available to award was $\$ 18,000$, following Council action last year to increase the award fund to $\$ 18,000$ from 15,000 . The maximum allowable award is $\$ 1800$.

Applicants must be APSA members and may not have received an APSA research grant in the previ- 